\title{
Triterpene Benzoates from the Bark of Picramnia teapensis (Simaroubaceae)
}

\section{Tatiana Rodríguez-Gamboa ${ }^{a}$, João B. Fernandes ${ }^{a^{*}}$, Edson Rodrigues Filho $^{a}$, M. Fátima das G. F. da Silva ${ }^{a}$, Paulo C. Vieira ${ }^{a}$, Mariano Barrios Ch. ${ }^{b}$, Oscar Castro-Castillo ${ }^{b}$,Sandra R. Victor ${ }^{c}$, Fernando C. Pagnocca ${ }^{c}$, Odair C. Bueno ${ }^{c}$ and Maria J. A. Hebling ${ }^{c}$}

\author{
${ }^{a}$ Departamento de Química, Universidade Federal de São Carlos, CP 676, 13565-905, São Carlos - SP, Brazil \\ ${ }^{\mathrm{b}}$ Departamento de Química, Universidad Nacional, Heredia, Costa Rica \\ ${ }^{\mathrm{c}}$ Centro de Estudo de Insetos Sociais, Unversidade Estadual Paulista Júlio de Mesquita, CP 199, 13506-900, \\ Rio Claro - SP, Brazil
}

\begin{abstract}
Da casca do caule de Picramnia teapensis Tul. foram isolados dois novos benzoatos triterpênicos, o $3 \alpha, 7 \beta$-dibenzoato do ácido lup-20(29)-en-28-óico e o $7 \beta$-benzoato do ácido $3 \alpha$ hidroxi-lup-20(29)-en-28-óico. A elucidação estrutural desses compostos foi fundamentada na análise dos dados espectroscópicos. Outros compostos conhecidos, $\beta$-sitosterol, estigmasterol, lupeol e epilupeol, foram identificados em mistura por CG-EM. Nenhum dos triterpenos benzoilados mostrou efeito inibitório no crescimento in-vitro do Leucoagaricus gongylophorus (Fisher), também citado como Leucocoprinus gongylophorus (Heim), syn Rozites gongylophora (Möller), o fungo simbionte cultivado pelas formigas cortadeiras de folhas Atta sexdens L.
\end{abstract}

Two new benzoic acid esters of triterpene alcohols [lup-20(29)-en-28-oic acid $3 \alpha, 7 \beta$-dibenzoate and $3 \alpha$-hydroxy-lup-20(29)-en-28-oic acid $7 \beta$-benzoate] were isolated from the stem bark of Picramnia teapensis Tul. The structures of these compounds were established on the basis of spectral analyses. Other known compounds, $\beta$-sitosterol, estigmasterol, lupeol and epilupeol, were identified in mixture by GC-MS. The triterpene esters have not shown in-vitro inhibitory effect on the growth of Leucoagaricus gongylophorus (Fisher), referred also as Leucocoprinus gongylophorus (Heim), syn Rozites gongylophora (Möller), the symbiotic fungus cultivated by the leaf-cutting ant Atta sexdens L.

Keywords: Triterpene esters, lupanes, Picramnia teapensis, Atta sexdens, Leucoagaricus gongylophorus

\section{Introduction}

The genus Picramnia is restricted to the neotropic region. According to Engler, the genus Picramnia belongs to Simaroubaceae, but Fernando \& Quinn have promoted Picramnia to a new family named Picramniaceae ${ }^{1}$.

We have previously described our findings on the chemical study of $P$. teapensis, a tree found in Central America $^{2,3}$. The study of the ethyl acetate extract of the stem bark from this plant has led to the isolation and characterization of two $C$-glycosylated anthrones (picramniosides D, E); two $C$-glycosylated oxanthrones (mayoside and mayoside $\mathrm{B}$ ); a $C, O$-diglycosylated anthrone (picramnioside $\mathrm{F}$ ); a $C, O$-diglycosylated oxanthrone (mayoside $\mathrm{C}$ ); two anthraquinone glycosides ( $1-O-\beta$-Dglucopyranosyl emodin and $8-O-\beta$-D-glucopyranosyl

\footnotetext{
* e-mail: djbf@power.ufscar.br
}

emodin) as well as emodin and umbelliferone ${ }^{2,3}$. Some of them showed antifungal activity against Leucoagaricus gongylophorus the symbiotic fungus cultivated by the leafcutting ants Atta sexdens $\mathrm{L}^{3}$. These ants are known as serious pest in agriculture and forestry in Brazil ${ }^{4}$. During the last decade we have been looking for a natural control of this pest without ecological injury, working on toxicity and repellence of plant extracts and plant products potentially toxic to Atta and their symbiotic fungus ${ }^{5-7}$.

This report deals with the isolation and identification of new lupane triterpene benzoates, from the chloroform extract of the stem bark from P. teapensis and the test of antifungal activity of the isolated compounds.

\section{Results and Discussion}

The chloroform extract from the stem bark of $P$. teapensis afforded, in minor quantities, a mixture of 
compounds $\mathbf{1}$ and 2, which were separated by column chromatography on silica gel. The lupane triterpenes benzoates $\mathbf{1}$ and $\mathbf{2}$ were identified on the basis of spectroscopic data, including COSY, DEPT, HMQC and HMBC experiments. Compound $\mathbf{1}$ was identified as lup20(29)-en-28-oic acid 3 $\alpha, 7 \beta$-dibenzoate and compound $\mathbf{2}$, in minor quantities, was identified as $3 \alpha$-hydroxy-lup20(29)-en-28-oic acid $7 \beta$-benzoate by comparison of ${ }^{1} \mathrm{H}$ and ${ }^{13} \mathrm{C}$ NMR data with those of compound $\mathbf{1}$.

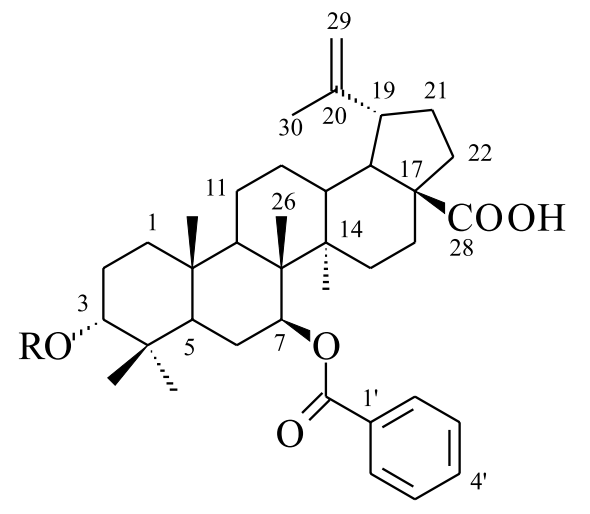

$$
\begin{aligned}
& 1 \mathrm{R}=\mathrm{PhCO} \\
& \mathbf{2} \mathrm{R}=\mathrm{H}
\end{aligned}
$$

Compound 1 had a molecular formula $\mathrm{C}_{44} \mathrm{H}_{56} \mathrm{O}_{6}$, as determined by ${ }^{13} \mathrm{C}$ NMR and DEPT analysis and confirmed by HREIMS. The IR spectrum of 1 exhibited bands at 3428 $\mathrm{cm}^{-1}$ ( $v$ O-H, broad), $2929 \mathrm{~cm}^{-1}$ (terminal methylene function), $1713 \mathrm{~cm}^{-1}$ ( $v \mathrm{C}=\mathrm{O}$ of ester function), $1274 \mathrm{~cm}^{-1}$, $1114 \mathrm{~cm}^{-1}(v \mathrm{C}-\mathrm{O})$ and $713 \mathrm{~cm}^{-1}$ (aromatic ring). The ${ }^{1} \mathrm{H}$ NMR spectrum of $\mathbf{1}$ displayed six signals for methyl groups at $\delta 0.93,0.95,0.96,1.18,1.31$ and 1.69 . This last value suggested the presence of one methyl group attached to an unsaturated carbon. Furthermore, vinylic protons signals appeared at $\delta 4.74(1 \mathrm{H}, \mathrm{d}, J 1.6 \mathrm{~Hz})$ and $\delta 4.61(1 \mathrm{H}, \mathrm{s})$ and the signal for one allylic proton appeared at $\delta 3.01$ (broad td, $J 11.1,4.6 \mathrm{~Hz}$ ). The spectrum also showed two acycarboxylic protons at $\delta 4.87$ (broad t, $J 2.6 \mathrm{~Hz}$ ) and $\delta$ $5.40(\mathrm{dd}, J 10.1,5.2 \mathrm{~Hz})$. Signals at $\delta 7.46-8.10(10 \mathrm{H})$ showed the typical pattern of the benzoate group (Table 1 ), the integration indicating the presence of two benzoate groups.

The ${ }^{13} \mathrm{C}$ NMR spectrum of $\mathbf{1}$ confirmed the nature of the triterpene skeleton, as a lup-20(29)-ene triterpenoid structure, with signals of the terminal olefinic bond at $\delta$ 150.3 and 109.8. Key signals indicated other functional groups of the lupane skeleton: $i$ ) the signal at $\delta 179.3$ corresponding to a carbonyl carbon of a carboxylic acid function, ii) two carbonyl carbons of conjugated ester functions ( $\delta 166.0$ and 165.8) and aromatic signals corresponding to the benzoic ester ring, and iii) two signals of carbinolic carbons ( $\delta 78.7$ and 77.6). The assignments of ${ }^{13} \mathrm{C}$ and ${ }^{1} \mathrm{H}$ RMN spectra are shown in Table 1 and the data are supported by the DEPT, COSY, HMQC and HMBC experiments. These assignments are comparable with those of structures with the same skeleton previously reported ${ }^{8}$. The location of the benzoate groups was established as follows: the signal at $\delta 4.87$ (broad t, $2.6 \mathrm{~Hz}$ ), corresponding to $\mathrm{H}-3$, showed correlation with the carbonyl of the benzoate at $\delta 166.0$ in the HMBC experiment and the coupling constant indicates an equatorial position of this proton, so the benzoate group must be $\alpha$. The shielding effect suffered by C-1 $(\delta 34.2)$ and C-5 ( $\delta$ 49.2) confirmed the relative configuration at $\mathrm{C}-3$. The position of the benzoate at $\mathrm{C}-7$ was determined by the observation of the correlations, in an HMBC experiment (Table 2), of the protons at Me-26 with C7, C-8, C-9 and C-14, and also of $\mathrm{H}-7$ with $\mathrm{C}-26$. The high shielding effect observed for the methyl at C-26 $(\delta$ 11.7) is reported for skeletons with hydroxyl or esterification in the $\beta$ position at $\mathrm{C}-7^{8,9}$. The coupling constants exhibited by $\mathrm{H}-7(5.2$ and $10.1 \mathrm{~Hz})$ indicate that it must be axial, so the relative configuration at $\mathrm{C}-7$ is with the benzoic ester in the $\beta$ position.

EIMS data of compound 1 exhibited the expected ester fragmentation, benzoic acid being a prominent eliminated product, with fragments at $m / z 558$ ([M-PhCO $\left.\left.{ }_{2} \mathrm{H}\right]\right)$ and $m / z$ $436\left(\left[\mathrm{M}-2 \mathrm{PhCO}_{2} \mathrm{H}\right]\right)$. The molecular ion peak at $\mathrm{m} / \mathrm{z} 680$, the base peak at $\mathrm{m} / z, 105\left(\left[\mathrm{C}_{6} \mathrm{H}_{5} \mathrm{CO}\right]^{+}\right)$, and other important fragments at $m / z, 635\left(\left[\mathrm{M}-\mathrm{HCO}_{2} \mathrm{H}\right]\right), 248,202,201,188$, 187 and 173 were observed (Figure 1). The fragmentation pattern strongly indicated the nature of the lup-20(29)-ene with esterifications at rings $\mathrm{A} / \mathrm{B}$.

Compound 2, $\mathrm{C}_{37} \mathrm{H}_{52} \mathrm{O}_{5}$, exhibited the same spectroscopic characteristics as $\mathbf{1}$, with exception of those of ring $\mathrm{A}$, having the following main ${ }^{1} \mathrm{H}$ and ${ }^{13} \mathrm{C}$ NMR data differences: the spectra showed the presence of only five aromatic protons showing the characteristic pattern of a benzoic group; the signal for $\mathrm{H}-3$, in a $\beta$ orientation, appeared as a shielded broad triplet at $\delta 3.42$. Therefore the signal of C-2 ( $\delta 25.4)$ was deshielded and the C-3 signal $(\delta$ 75.9) shielded in comparison with the signals in $\mathbf{1}$, as occurs in other lupanes with 3- $\alpha$-hydroxyl ${ }^{8}$.

Compound 2 was isolated in too small amount to observe all the quaternary carbons by ${ }^{13} \mathrm{C}$ NMR. ${ }^{1} \mathrm{H}$ and ${ }^{13} \mathrm{C}$ NMR attributions shown in Table 1 are consistent with the observations made in DEPT 135 and HMBC experiments. The correlations observed by HMBC were basically from the six methyl groups on the lupane skeleton (Table 2). The correlation of C-26 and C-2' with $\mathrm{H}-7$ confirmed the position of the benzoic ester. Some signals were attributed by comparison with the data of compound $\mathbf{1}$. 
<smiles>C=C(C)C1CCC2(C(=O)O)CCC(C)C(C[CH2+])C12</smiles><smiles>C=C(C)C1CCC2=C1C(C[CH2-])C(C)CC2</smiles><smiles>C=C(C)C1CCC2=C1/C(=C/[CH2+])C(C)CC2</smiles>

$m / z 248(1,0.5 \% ; 2,0.5 \%)$

$m / z 202$ (5 and 1) $m / z 201$ (7 and 4)<smiles>CC1=CC2(C)CC=CC(C)(C)C2[CH+]C1</smiles>

$m / z 188$ (6 and 5)<smiles>CC1=CC2(C)CC=CC(C)(C)C2=C[CH+]1</smiles>

$m / z 187(7$ and 10)<smiles>C=CC=C[C@@H]1C(C)(C)C=CCC1(C)C</smiles>

$m / z 173$ (6 and 7)

Figure 1. Some EIMS fragments of compounds 1 and 2

Table 1. ${ }^{13} \mathrm{C}$ NMR (100 MHz) and ${ }^{1} \mathrm{H}$ NMR (400 MHz) chemical shifts for compounds $\mathbf{1}$ and $\mathbf{2}\left(\mathrm{CDCl}_{3}\right.$, TMS)

\begin{tabular}{|c|c|c|c|c|}
\hline \multirow[b]{2}{*}{$\mathrm{C}$} & \multicolumn{2}{|c|}{ Compound 1} & \multicolumn{2}{|c|}{ Compound 2} \\
\hline & $\delta_{\mathrm{C}}$ & $\delta_{\mathrm{H}}$ & $\delta_{\mathrm{C}}$ & $\delta_{\mathrm{H}}$ \\
\hline 1 & 34.2 & $1.18-1.28 \mathrm{~m}, 1.54-1.60 \mathrm{~m}$ & 33.3 & $1.05 \mathrm{~m}$ \\
\hline 2 & 22.9 & $1.82-1.85 \mathrm{~m}, 1.95-2.00 \mathrm{~m}$ & $25.4^{\mathrm{b}}$ & \\
\hline 3 & 78.7 & 4.87 br t (2.6) & 75.9 & 3.42 br t (2.2) \\
\hline 4 & 37.4 & - & 37.6 & - \\
\hline 5 & 49.2 & $1.48-1.57 \mathrm{~m}$ & 46.2 & 0.81 \\
\hline 6 & $25.3^{\mathrm{a}}$ & $1.55-1.98 \mathrm{~m}$ & $25.4^{\mathrm{b}}$ & \\
\hline 7 & 77.6 & $5.40 \mathrm{dd}(5.2,10.1)$ & 77.6 & $5.32 \mathrm{dd}(4.7,10.1)$ \\
\hline 8 & 46.2 & - & 46.0 & - \\
\hline 9 & 50.8 & $1.54-1.60 \mathrm{~m}$ & 50.7 & $1.45 \mathrm{~m}$ \\
\hline 10 & 37.1 & - & 37.6 & - \\
\hline 11 & 20.4 & $1.60-1.67 \mathrm{~m}$ & 20.4 & \\
\hline 12 & $25.5^{\mathrm{a}}$ & $1.55-1.98 \mathrm{~m}$ & $25.5^{\mathrm{b}}$ & \\
\hline 13 & 38.7 & $2.27 \mathrm{br} \mathrm{dt}(2.1,13.0)$ & 38.7 & $2.25 \mathrm{~m}$ \\
\hline 14 & 43.8 & - & 43.9 & - \\
\hline 15 & 32.3 & & 32.2 & \\
\hline 16 & 32.6 & $2.10 \mathrm{dt}(13.0,2.1), 1.36-1.46 \mathrm{~m}$ & 32.5 & \\
\hline 17 & 55.9 & - & 55.9 & - \\
\hline 18 & 47.9 & $1.60-1.67 \mathrm{~m}$ & 49.2 & \\
\hline 19 & 47.1 & $3.01 \mathrm{br} d t(4.6,11.1)$ & 47.2 & $3.00 \mathrm{br} \mathrm{dt}(5.2,11.0)$ \\
\hline 20 & 150.3 & - & 150.4 & - \\
\hline 21 & 30.6 & $1.36-1.46 \mathrm{~m}, 1.95-2.00 \mathrm{~m}$ & 30.6 & \\
\hline 22 & 37.1 & $1.44-1.54 \mathrm{~m}, 1.94-1.98 \mathrm{~m}$ & 37.1 & \\
\hline 23 & 27.9 & $0.96 \mathrm{~s}$ & 28.0 & $0.96 \mathrm{~s}$ \\
\hline 24 & 21.7 & $0.93 \mathrm{~s}$ & 22.0 & $0.80 \mathrm{~s}$ \\
\hline 25 & 15.7 & $0.95 \mathrm{~s}$ & $15.7^{\mathrm{b}}$ & $0.89 \mathrm{~s}$ \\
\hline 26 & 11.7 & $1.31 \mathrm{~s}$ & 11.6 & $1.26 \mathrm{~s}$ \\
\hline 27 & 15.2 & $1.18 \mathrm{~s}$ & $15.1^{\mathrm{b}}$ & $1.12 \mathrm{~s}$ \\
\hline 28 & 179.3 & - & n.o. ${ }^{c}$ & - \\
\hline 29 & 109.8 & $4.74 \mathrm{~d}(1.6), 4.61 \mathrm{~s}$ & 109.8 & $4.75 \mathrm{~s}, 4.62 \mathrm{~s}$ \\
\hline 30 & 19.5 & $1.69 \mathrm{~s}$ & 19.4 & $1.68 \mathrm{~s}$ \\
\hline $1^{\prime}$ & 131.0 & - & 131.0 & - \\
\hline $1 "$ & 131.2 & - & - & - \\
\hline $\mathrm{C}=\mathrm{O}\left(1^{\prime}\right)$ & 165.8 & - & 165.7 & - \\
\hline $\mathrm{C}=\mathrm{O}\left(1^{\prime \prime}\right)$ & 166.0 & - & - & - \\
\hline $2^{\prime}$ and $6^{\prime}$ & 129.6 & $8.03-8.08 \mathrm{dq}, 2 \mathrm{H}(9.6,0.7)$ & 129.6 & 8.00 br d (7.6) \\
\hline 2" and 6" & 129.6 & $8.01-8.07 \mathrm{dq}, 2 \mathrm{H}(9.6,0.6)$ & - & - \\
\hline $3^{\prime}$ and $5^{\prime}$ & 128.4 & $7.46 \mathrm{br} \mathrm{td}, 2 \mathrm{H}(7.6,0.6)$ & 128.4 & 7.44 br t (7.7) \\
\hline $3 "$ and 5" & 128.5 & $7.51 \mathrm{br} \mathrm{td}, 2 \mathrm{H}(6.1,0.7)$ & - & - \\
\hline $4^{\prime}$ & 132.8 & $7.56-7.61 \mathrm{br} \mathrm{dt}, 1 \mathrm{H}(8.7,1.1)$ & 132.7 & 7.55 br t $(7.1)$ \\
\hline $4 "$ & 132.8 & 7.59 ddt $1 \mathrm{H}(8.7,8.0,0.7)$ & - & - \\
\hline
\end{tabular}

a, b may be interchangeable.

${ }^{\mathrm{c}}$ not observed. 
Table 2. ${ }^{1} \mathrm{H}-{ }^{13} \mathrm{C}$ correlations observed on $\mathrm{HMBC}$ experiment for $\mathbf{1}$ and 2.

\begin{tabular}{|c|c|c|}
\hline & Compound 1 & Compound 2 \\
\hline $\mathrm{H}$ & $\mathrm{C}$ & $\mathrm{C}$ \\
\hline 2 & 4,10 & \\
\hline 3 & $1,1^{\prime \prime}, 3$ & n.o. \\
\hline 5 & $7,10,24,25$ & \\
\hline 7 & 7,26 & n.o. \\
\hline 18 & $17,20,28$ & n.o. \\
\hline 19 & 18 & n.o. \\
\hline 23 & $3,4,5,24$ & $3,4,5,24$ \\
\hline 24 & $3,4,5,23$ & $3,4,5,23$ \\
\hline 25 & $1,5,9,10$ & $1,5,9,10$ \\
\hline 26 & $7,8,9,14$ & $7,8,9,14,27$ \\
\hline 27 & $8,13,14,15$ & $8,13,14,15$ \\
\hline 29 & $19,29,30$ & 19,30 \\
\hline 30 & $19,29,30$ & $19,20,29$ \\
\hline $2^{\prime}$ and $6^{\prime}$ & $2^{\prime}, 6^{\prime}, 1^{\prime} \mathrm{C}=\mathrm{O}$ & $1^{\prime} \mathrm{C}=\mathrm{O}, 2^{\prime}, 4^{\prime}, 6^{\prime}$ \\
\hline $2^{\prime \prime}$ and 6"' & $2^{\prime \prime}, 6^{\prime \prime}, 1^{\prime \prime} \mathrm{C}=\mathrm{O}$ & \\
\hline $3^{\prime}$ and $5^{\prime}$ & $1^{\prime}, 3^{\prime}, 5^{\prime}$ & $1^{\prime}, 3^{\prime}, 5^{\prime}$ \\
\hline $3^{\prime \prime}$ and 5" & $1^{\prime \prime}, 3^{\prime \prime}, 5^{\prime \prime}$ & \\
\hline $4^{\prime}$ & $2^{\prime}, 6^{\prime}$ & $2^{\prime}, 6^{\prime}$ \\
\hline 4" & 2', 6"' & \\
\hline
\end{tabular}

The EIMS spectrum of compound $\mathbf{2}$ did not show the molecular ion peak because of the lost of benzoic acid. Some of the observed fragments were at $\mathrm{m} / \mathrm{z} 454$ ([M$\left.\left.\mathrm{C}_{6} \mathrm{H}_{5} \mathrm{CO}_{2} \mathrm{H}\right]\right), m / z 122\left(\left[\mathrm{C}_{6} \mathrm{H}_{5} \mathrm{CO}_{2} \mathrm{H}\right]^{+} \cdot\right)$ and $m / z 105$ $\left(\left[\mathrm{C}_{6} \mathrm{H}_{5} \mathrm{CO}\right]^{+}\right)$, being the base peak at $\mathrm{m} / z 77\left(\left[\mathrm{C}_{6} \mathrm{H}_{5}\right]^{+}\right)$. The fragmentation pattern shown in Figure 1 was also observed as in compound $\mathbf{1}$.

The chloroform extract from the stem bark of $P$. teapensis also afforded a mixture of $\beta$-sitosterol, stigmasterol, lupeol and epilupeol which were identified by GC-MS and by comparison of EIMS spectra and co-injection in GC of authentic samples available in our laboratory.

Compounds $\mathbf{1}$ and $\mathbf{2}$ were tested in the growth inhibition assay of Leucoagaricus gongylophorus, using the methodology described by Pagnocca et al. ${ }^{5}$. These new compounds have not shown inhibitory effect against growth of $L$. gongylophorus at concentration of $100 \mu \mathrm{g} \mathrm{mL}^{-1}$. 1$O-\beta$-D-Glucopyranosyl emodin and $8-O-\beta$-D-glucopyranosyl emodin, isolated from this plant, were used as positive controls since they showed complete inhibition of the fungus growth at a concentration of $50 \mu \mathrm{g} \mathrm{mL}^{-13}$.

\section{Experimental}

\section{General}

CC: Silica gel 230-400 Mesh (Merck). TLC: Silica gel 60 F254 (Merck). Melting points uncorr. IR: BOMEM-FT-
IR, model Michaelson-100 spectrophotometer. UV $\left(\mathrm{CH}_{2} \mathrm{Cl}_{2}\right)$ : Hewlett Packard, model 8452A. Optical rotation $\left(\mathrm{CH}_{2} \mathrm{Cl}_{2}\right)$ : Perkin Elmer $241 \mathrm{MC} .{ }^{1} \mathrm{H}$ NMR $(400 \mathrm{MHz})$ and ${ }^{13} \mathrm{C}$ NMR (100 MHz): Bruker ARX-400 spectrometer, in $\mathrm{CDCl}_{3}$ containing TMS as int. standard, using 5 (1) and 2.5 (2) mm sample tubes. GC-MS: Shimadzu QP 5000 system, DB-5 (J\&W) capillary column ( $30 \mathrm{~m}$ x $0.25 \mathrm{~mm}$ ID, $0.25 \mu \mathrm{m}$ film thickness) with helium as the carrier gas at a flow rate of $1.6 \mathrm{~mL} \mathrm{~min}^{-1}$; the temperature program was $150{ }^{\circ} \mathrm{C} \mathrm{min}-1$ and increased at a rate of $10{ }^{\circ} \mathrm{C} \mathrm{min}^{-1}$ to $250{ }^{\circ} \mathrm{C}$, standing $25 \mathrm{~min}$ at this temperature; injection in the split mode (10:1) at an injector, temperature of $225^{\circ} \mathrm{C}$; the interface temperature was $250{ }^{\circ} \mathrm{C}$; mass spectra were recorded in the EI mode at $70 \mathrm{eV}$. EIMS $(70 \mathrm{eV})$ : VG Platform II instrument. HRMS: Autospec-Micromass EBE. Elemental analysis: Fisons Instruments model EA 1108 CHNS-O.

\section{Plant material}

The stem bark of P. teapensis was collected in Costa Rica, in the region of San José de la Montana in September 1990 and identified by Dr. Luis Jorge Poveda. A voucher (CR194274) was deposited in the herbarium of the Universidad Nacional of Costa Rica, Heredia.

\section{Extraction and isolation of the chemical constituents}

Dried and powdered stem bark of P. teapensis (615 g) was macerated with EtOH $80 \%$. The extract was filtered and concentrated under vacuum, and part of it (10.3 g) was partitioned between $\mathrm{H}_{2} \mathrm{O}$ and $\mathrm{CHCl}_{3}$. VLC fractionation of the concentrated chloroform layer $(2.37 \mathrm{~g})$ on silica gel was carried out, eluting with hexane- $\mathrm{CH}_{2} \mathrm{Cl}_{2}$ and $\mathrm{CH}_{2} \mathrm{Cl}_{2}^{-}$ $\mathrm{MeOH}$ mixtures of increasing polarity, to yield 50 fractions, $25 \mathrm{~mL}$ each. These fractions were combined in 12 groups on the basis of analytical TLC. Fraction 5 (107.3 mg) was crystallized in $\mathrm{CH}_{2} \mathrm{Cl}_{2}$ /acetone and its constitution was analyzed by GC-MS. Four compounds were identified from this fraction: $\beta$-sitosterol, estigmasterol, lupeol and epilupeo ${ }^{10}$. Fraction $6(160.8 \mathrm{mg})$ was submitted to chromatographic separations on silica gel columns using as eluents hexane, $\mathrm{CH}_{2} \mathrm{Cl}_{2}$ and $\mathrm{MeOH}$, and yielding the triterpene benzoates $\mathbf{1}(10.2 \mathrm{mg})$ and $\mathbf{2}(1.0 \mathrm{mg})$.

\section{Triterpene 1}

Viscous oil (10.2 mg). $[\alpha]_{\mathrm{D}}^{25}\left(\mathrm{CH}_{2} \mathrm{Cl}_{2} c\right.$ 0.063): -5.9; $\mathrm{UV} \lambda_{\max } / \mathrm{nm}(e): 230$ (1890), 274 (150). IR $v_{\text {max }} / \mathrm{cm}^{-1}: 3428$, 2929, 2861, 1713, 1454, 1274, 1114, 713 (film); ${ }^{1} \mathrm{H}$ NMR $\left(\mathrm{CDCl}_{3}, 400 \mathrm{MHz}\right)$ Table $1 ;{ }^{13} \mathrm{C} \mathrm{NMR}\left(\mathrm{CDCl}_{3}, 100 \mathrm{MHz}\right)$ 
Table 1; HREIMS: found $680.4076[\mathrm{M}]^{+}$, requires 680.4078; EIMS m/z (rel. int. \%) $680(0.2), 635$ (0.5) [M$\left.\mathrm{CO}_{2} \mathrm{H}\right]^{+}, 634$ (1) $\left[\mathrm{M}-\mathrm{HCO}_{2} \mathrm{H}\right]^{+}, 594(0.5)\left[\mathrm{M}-\mathrm{HCO}_{2} \mathrm{H}-40\right]^{+}$, 558 (2), 436 (5), 421 (7) [M-2 $\left.\mathrm{PhCO}_{2} \mathrm{H}-\mathrm{CH}_{3}\right]^{+}, 248(0.5)$, 202 (5), 201 (7), 188 (6), 187 (7), 173 (6), 122 (15) $\left[\mathrm{PhCO}_{2} \mathrm{H}\right]^{+}, 105(100)[\mathrm{PhCO}]^{+}, 77(60)\left[\mathrm{C}_{6} \mathrm{H}_{5}\right]^{+}$.

\section{Triterpene 2}

Viscous oil (1 mg). IR $v_{\text {max }} / \mathrm{cm}^{-1} 3420,2927,2865,1708$, 1454, 1274, 712, 615 (film); ${ }^{1} \mathrm{H}$ NMR ( $\left.\mathrm{CDCl}_{3}, 400 \mathrm{MHz}\right)$ Table $1 ;{ }^{13} \mathrm{C}$ NMR $\left(\mathrm{CDCl}_{3}, 100 \mathrm{MHz}\right)$ Table 1; EIMS $\mathrm{m} / \mathrm{z}$ (rel. int. \%) 455 (1) [M- $\left.\mathrm{PhCO}_{2}\right]^{+}, 554$ (2), 421 (5), 409 (1), 393 (4), 248 (0.5), 202 (1), 201 (4), 188 (5), 187 (10), 173 (7), 122 (35), 105 (87), 77 (100), 69 (71). Found: C, 77.1; H, 9.2. Calc. for $\mathrm{C}_{37} \mathrm{H}_{52} \mathrm{O}_{5}: \mathrm{C}, 77.0 ; \mathrm{H}, 9.1 \%$.

Leucoagaricus gongylophorus growth inhibition assay: as described by Pagnocca et al. ${ }^{5,6}$.

\section{Acknowledgement}

The authors would like to thank the Fundação de Amparo à Pesquisa do Estado de São Paulo (FAPESP), for scholarships and the financial support, as well as to PRONEX/MCT-FINEP, and Conselho Nacional de Desenvolvimento Científico e Tecnológico (CNPq).

\section{References}

1. Fernando, E. S.; Quinn, C. J. Taxon. 1995, 44, 177.

2. Rodríguez-Gamboa, T.; Fernandes, J. B.; Rodrigues Fo., E.; Da Silva, M. F. G. F.; Vieira, P. C.; Castro C., O. Phytochemistry 1999, 51, 583.

3. Rodríguez-Gamboa T.; Victor, S. R.; Fernandes J. B.; Rodrigues Fo., E.; Silva, M. F. G. F.; Vieira, P. C.; Pagnocca, F. C.; Bueno, O. C.; Hebling, M. J. A.; Castro C., O. Phytochemistry 2000, 55, 837.

4. Della Lucia, T.M.C. Abstracts of the VI International Pest Ant Symposium \& Encontro de Mirmecologia, Ilhéus, Brasil, 1997, 147.

5. Pagnocca, F. C.; Silva, O.A.; Hebling-Beraldo, M. J. A.; Bueno, O. C.; Fernandes, J. B.; Vieira, P. C. Bull. Entomol. Res. 1990, 80, 349.

6. Pagnocca, F. C.; Ribeiro, S.B.; Torkomian, V.L.V.; Hebling-Beraldo, M. J. A.; Bueno, O. C.; Silva, O. A.; Fernandes, J. B.; Vieira, P. C.; Da Silva, M. F. G. F.; Ferreira, A. G. J. Chem. Ecol. 1996, 22, 1325.

7. Hebling-Beraldo, M. J. A.; Bueno, O. C.; Almeida, R.E.D.; Silva, O. A. D.; Pagnocca, F. C. Abstracts of the Sociedade Entomológica do Brasil 1991, 20, 27.

8. Jiang, Z. H.; Tanaka, T.; Kouno, I. Phytochemistry 1995, 40, 1223.

9. Lee, S. S.; Lin, B. F.; Liu, K. C. Phytochemistry 1996, 43, 847.

10. Peraza-Sánches, S. R.; Salazar-Aguilar, N. E. and Peña-Rodriguez, L M. J. Nat. Prod. 1995, 58, 271.

Received: November 14, 2000

Published on the web: May 16, 2001

FAPESP helped in meeting the publication costs of this article. 